\title{
Childhood obesity and its cardiovascular implications: a current view
}

\author{
Ornelas, EM. *, Francica, JV., Wichi, RB. and Maifrino, LBM. \\ Pós-Graduação Stricto Sensu em Educação Física, Universidade São Judas Tadeu - USJT, \\ Rua Taquari, 546, Mooca, CEP 05503-000, São Paulo, SP, Brasil \\ *E-mail: prof.ornelas@hotmail.com
}

\begin{abstract}
Obesity is a universal disease of increasing prevalence and currently assumes epidemiological characteristic, as a main public health issue in contemporary society. Results from genetic, behavioral and environmental factors and it may start at any age. However, obesity appears at early ages predisposes to its presence at later ages bringing several complications, particularly the development of cardiovascular disease. The analysis indicates that autonomic dysfunction seems to be presented among the majority of risk factors that develop this disease, suggesting the need for a deeper study of this mechanism in children population
\end{abstract}

Keywords: childhood obesity, lipid profile, blood pressure, exercise.

\section{Introduction}

Based on scientific literature, it is observed that obesity is a universal disease of increasing prevalence and currently assumes an epidemiological characteristic as a main public health issue in contemporary society. Multifactorial, it results from the overlap of genetic, behavioral and environmental factors and can start at any age. The current dietary habits and decreasing levels of physical activity have provided the increase of obesity and overweight in children and adolescents.

Regarding childhood obesity, object of this study, it is perceived that obesity brings many implications for health in adulthood, especially in the development of cardiovascular diseases. Analysis of the hemodynamic and metabolic profile reveals this condition.

\section{Adipose tissue}

Adipose tissue is a dynamic organ, consisting of a special type of tissue characterized by the presence of cells specialized in lipid storage, known as adipocytes. Adipocytes besides its important role as a body energy reservoir secrete numerous factors, called adipokines that act on adipocytes themselves and other body tissues by modulating the functional behavior of adipose tissue and other organs (Figure 1).

Most of the adipokines are related, directly or indirectly, to the processes that contribute to atherosclerosis, hypertension, insulin resistance (IR) and diabetes mellitus type 2 (DMT2) dyslipidemia, ie, represent the link between adiposity, metabolic syndrome and cardiovascular diseases (ARNER, 1995; HSUEH and LAW, 2003; RAJALA and SCHERER, 2003; LYON, LAW, and HSUEH, 2003).

In obesity, body fat deposits are increased, presenting consequent rise in the expression and secretion of the adipokines in proportion to the higher volume of fat cells. The different fat deposits, such as visceral adipose tissue, abdominal subcutaneous, gluteal-femoral subcutaneous and intramuscular have, different metabolic and endocrine degrees and may be thus interfering, in the processes associated with body adiposity on obese and diabetics in a specific form (HERMSDORFF and MONTEIRO, 2004).

\section{Childhood obesity}

The worldwide prevalence of childhood obesity has been showing a rapid increase in recent decades, it is characterized as a true epidemic. According to the estimates by the International Obesity Task Force - IOTF (2002), 22 million children under 5 years of age worldwide are obese.

This fact is rather worrying, because the association of obesity with metabolic alterations such as dyslipidemia, hypertension and glucose intolerance, considered risk factors for diabetes mellitus type II and cardiovascular disease until a few years ago were more evident in adults. However, today can already be frequently observed in the youngest age groups (STYNE, 2001).

Several scientific studies conceptualize obesity as an accumulation of adipose tissue, both in childhood and adolescence and adulthood, distributed throughout the body (OLIVEIRA, MELLO, CINTRA et al., 2004; MARQUESLOPES, MARTI, MORENO-ALIAGA et al., 2004; SABIA, SANTOS and RIBEIRO, 2004; PITANGA and LESSA, 2005; HALPERN, MANCINI, CERCATO et al., 2006). Still regarded as a universal disease of increasing prevalence, obesity nowadays assumes an epidemiological characteristic as the main public health issue in society.

International guidelines on obesity suggest that children above the 85 th percentile are considered overweight, and above 95 percentile are considered obese (BUNDRED, KITCHNER and BUCHAN et al., 2001). In the United States, the prevalence of obesity in children range 5 to $11 \%$ (SOROF and DANIELS, 2002). In Italy, approximately $14 \%$ of children aged 4-12 years are obese. Differences in nutritional and behavioral habits between countries are common and may partially explain the different prevalences of obesity that have been presented in epidemiological studies (MAFFEIS, TALAMINI and TATÒ, 1998). 


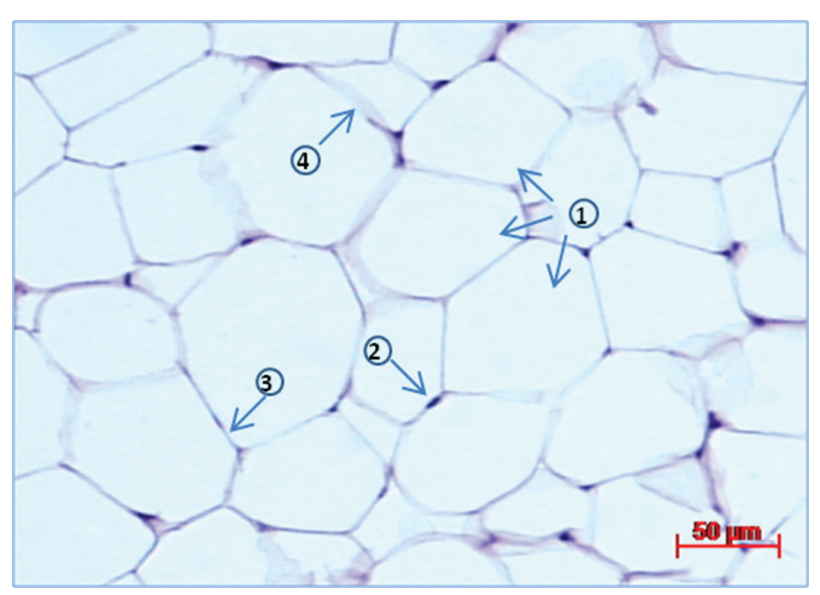

Figure 1. Micrograph of white unilocular Adipose Tissue (AT). It is observed adipocytes (1) core (2), the thin membrane around the cytoplasm (3) and the supporting framework formed by reticular fibers $(100 \mathrm{X})$.

According to Silva, Balaban and Motta (2005) socioeconomic status interferes with the availability of food and access to information, being influenced by education, income and occupation, resulting in specific behavioral patterns that affect energy intake, energy expenditure and metabolism rate. However, as healthy foods are less available to individuals under more restricted conditions, the relation between obesity and lower socioeconomic class are observed in developing countries (GRILLO, CARVALHO, SILVA et al., 2000).

In Brazil, obesity appears in different economic classes, especially in the Upper social classes. Assessing children from two schools with different socioeconomic conditions in the city of São Paulo, Miranda, Silva, Koike et al. (2007) found a prevalence of overweight and obesity in boys (19.6\% - 34.8\%) and girls $(25.5 \%-31.9 \%)$ in private respectively public school and school $(6.7 \%-6.7 \%)$ and for boys $(8.1 \%-6.5 \%)$ for girls.

Oliveira and Veiga (2005) perceived changes in dietary habits, influenced by advertisements and fads that end up encouraging the consumption of too much food with higher energy density. Inventories of energy in the body are regulated by intake and the energy expenditure. When there is balance between food intake and energy expenditure, body weight is maintained. A small positive balance entails low weight gain, but the chronic imbalance between intake and expenditure leads to obesity over time (SIGULEM, TADDEI, ESCRIVÃO et al., 2001). In this context, it can be said that obesity is an energy metabolism disorder.

Regarding the analysis of the relation between the decreased levels of physical activity of children and adolescents with increasing obesity, some studies are revealing. Giugliano and Carneiro (2004), indicate that 75\% of the routine overweight or obese children is distributed in hours of sleep and sitting, showing a strong correlation between body fat percentage and daily time spent. Excessive hours in front of television has been frequently associated with obesity, since during this time the individual increases the intake of processed foods experiencing a reduction in energy expenditure (TITO, 2000). Children have become less active, encouraged by technological advances, spend it sitting or lying hours watching television, playing video games or using the computer. This makes the energy expenditure lower compared to children playing outdoors, running and practicing physical activity (ATENAS and VITOLO, 2004; GIUGLIANO and CARNEIRO, 2004). Children, who do not practice regular physical activity, preferring sedentary activities, spend less energy than the most active, stimulating the fat deposit. Therefore less active child, even when not eating in excess, have a higher risk of becoming overweight (ATENAS and VITOLO, 2004).

Obesity occurs more frequently in the early ages, between 5 and 6 years and adolescence (EBBELING, PAWLAK and LUDWIG, 2002). When appears early in the first years of life, predisposes to its presence in the later ages, probably due to irreversible hyperplasia of adipocytes. If obesity persists throughout middle childhood (6-12 years) and adolescence, the prognosis worsens, allowing the maintenance of obesity risk factors (GUERRA, TEIXEIRA, SANTOS et al., 1990; GUERRA, TEIXEIRA, GUERRA et al., 1993).

\section{Obesity and its cardiovascular disease risk factors}

The risk factor can be defined as one which presence is associated with an increased probability in which a particular disease will subsequently develop (RABELO, 2001).

The manifestation of cardiovascular disease in adulthood results from a complex interaction between a variety of risk factors that may have originated in childhood and adolescence (BERENSON, SRINIVASAN, BAO et al., 1998). Obesity complications associated with cardiovascular disease include hypertension, dyslipidemia, insulin resistance, glucose intolerance, diabetes mellitus type II, left ventricular hypertrophy, and pulmonary hypertension resulting in obstructive sleep apnea (DIETZ, 1998).

Youngsters, who may present risk factors with advancing age, tend to be more predisposed to the development of atherosclerosis and subsequent development of cardiovascular disease (GUEDES, GUEDES, BARBOSA et al., 2006). Anatomopathological studies observed associations between dyslipidemia and other atherosclerotic diseases, especially coronary arteries. The presence of fatty streaks, which are considered precursors of atherosclerotic plaques from 3 years of age in the aorta and $15 \%$ impairment of this artery to 15 years, thereafter arise in the coronary (McGILL JUNIOR, GEER and STRONG, 1963).

In a study conducted in the city of Campinas with 1,600 schoolchildren aged 7-14 years, where found 35\% prevalence of hypercholesterolemia. Girls presented higher values than boys (MOURA, CASTRO, MELLIN et al., 2000). The association between obesity, total cholesterol and LDL-cholesterol increased the risk for developing atherosclerotic disease, and low levels of HDL - cholesterol, further increasing this risk by the anti-atherogenic fraction (NOBRE, DOMINGUES, SILVA et al., 2006).

Obese children may also show early changes in the myocardium and disorders of carotid and coronary arteries. Changes in vascular structure and function were found in obese children with diabetes mellitus and family history of hypercholesterolemia, which when studied by ultrasound of the carotid arteries showed a decrease in intima-media 
thickness (TONSTAD, JOAKINSEN, STENSLANDBUGGE et al., 1996).

Gama, Carvalho and Chaves (2007) investigated the presence of risk factors for cardiovascular disease in children 5-9 years old, at the basic health care of Rio de Janeiro metropolitan areas and observed $10.7 \%$ of overweight and $68.4 \%$ with abnormal lipid profile, with $18.6 \%$ with high LDL-cholesterol, $35 \%$ change in HDL-C and $3.5 \%$ of the triglyceride. High triglyceride value, decreased lipoprotein HDL-C and an increase in LDL-C and triglyceride twenty times increase in the development of coronary heart disease (BERENSON, SRINIVASAN, BAO et al., 1998).

In the first two years of age and during sexual maturation, serum lipoproteins and lipid levels range markedly. The 2 years of age individual, reaches cholesterol levels that must be maintained throughout the first decade of life, regardless of gender or race. During puberty the levels of triglycerides and VLDL-c increase in all children (RABELO, 2001). Obesity is strongly associated with an altered lipid profile, and compared the genre, is more evident in boys than in girls. The increased level of VLDL is the most significant lipid disorders associated with excess weight (BERENSON, SRINIVASAN, BAO et al., 1998).

Regarding the pathophysiology of obesity, it is found that most studies is derived from analyzes with and adult animals. On few children have focused the investigation of three pathophysiological mechanisms for the development of hypertension in childhood, which are: disturbances in autonomic function, insulin resistance and abnormalities in vascular structure and function (SOROF and DANIELS, 2002).

The relation between obesity and hypertension can be measured in part by the hyperactivity of the sympathetic autonomic nervous system. This state can include cardiovascular manifestations such as an increase in heart rate variability and blood pressure, neurohumoral manifestations, as well as increased plasma levels of catecholamine, and neural manifestations such as peripheral sympathetic hyperactivity (JIANG, SRINIVASAN, URBINA et al., 1995).

Such studies suggest that changes in heart rate variability in obese children can be related to a change in sympathovagal balance, not only by increased sympathetic activity alone (SOROF and DANIELS, 2002). Physical training is an alternative in reducing the sympathovagal balance, suggesting that autonomic function is an important mechanism in the pathogenesis of childhood obesity, as well as in adults (GUTIN, OWENS, SLAVENS et al., 1997).

Recent evidence suggests that leptin may be the link between obesity and increased sympathetic activity. Leptin acts directly on the hypothalamus to increase sympathetic activity, and its effects on appetite control and metabolism. Hiperinsulinemia may also participate in the development of sympathetic hyperactivity in obesity. Thus, both insulin and leptin are able to increase sympathetic activity directed to the kidneys even in obese animals (CARVALHEIRA, TORSONI, UENO et al., 2005). On activation of the sympathetic nervous system probably other mechanisms involved that should be considered are the low serum levels of ghrelin and adiponectin and high levels of circulatingfree fatty acids (RAHMOUNI, CORREIA, HAYNES et al., 2005).
Obesity is also a common cause of obstructive sleep apnea syndrome in children, due to increased respiratory effort by fat deposition in the pharynx and increased abdominal and thoracic volume (VALERA, DEMARCO and ANSELMOLIMA, 2004). Obese adults in the interaction between obstructive sleep apnea and sympathetic hyperactivity, reinforces the involvement of this mechanism in the pathogenesis of various diseases related to obesity.

Exists a positive association between insulin levels and resting blood pressure in obese children and young adults, however these correlations were found only in hypertensive obese children, not observable in normotensive obese group (YOUNG-HYMAN, SCHLINDT, HERMAN et al., 2001).

\section{Conclusion}

Despite constant evidence about the increase in childhood obesity worldwide, and there are many investigations on possible mechanisms involved, we realize that some aspects still need further attention. Conflicting points involving these specific risk factors and most population studies are performed with experimental animals and adults. However, according to the survey presented we conclude that autonomic dysfunction seems to be present in most risk for developing cardiovascular disease factors, suggesting the need to delve into the study of this mechanism in this specific population.

\section{References}

ARNER, P. Differences in lipolysis between human subcutaneous and omental adipose tissues. Annals of Medicine, 1995, vol. 27, n. 4, p. 435-438. PMid:8519504. http://dx.doi. org/10.3109/07853899709002451

ATENAS, MLB. and VITOLO, MR. Crescendo com saúde. São Paulo: C2, 2004.

BERENSON, GS., SRINIVASAN, SR., BAO, W., NEWMAN, WP 3rd, TRACY, RE. and WATTIGNEY, WA. Association between multiple cardiovascular risk factors and atherosclerosis in children and young adults. New England Journal of Medicine, 1998, vol. 338, n. 23, p. 1650-1656. PMid:9614255. http://dx.doi. org/10.1056/NEJM199806043382302

BUNDRED, P., KITCHNER, D. and BUCHAN, I. Prevalence of overweight and obese children between 1989 and 1998: population based series of cross sectional studies. British Medical Journal, 2001, vol. 322, n. 7282, p. 326-328. PMid:11159654 PMCid:PMC26573. http://dx.doi.org/10.1136/bmj.322.7282.326

CARVALHEIRA, JB., TORSONI, MA., UENO, M., AMARAL, ME., ARAUJO, EP., VELLOSO, LA., GONTIJO, JA. and SAAD, MJ. Cross-talk between the insulin and leptin signaling systems in rat hypothalamus. Obesity Research, 2005, vol. 13, n. 1, p. 48-57. PMid:15761162. http://dx.doi.org/10.1038/oby.2005.7

DIETZ, WH. Health consequences of obesity in youth: childhood predictor of adult disease. Pediatrics, 1998, vol. 101, p. 518-525. PMid:12224658.

EBBELING, CB., PAWLAK, DB. and LUDWIG, DS. Childhood obesity: public-health crisis, common sense cure. Lancet, 2002, vol. 360, n. 9331, p. 473-482. http://dx.doi.org/10.1016/ S0140-6736(02)09678-2 
GAMA, SR., CARVALHO, MS. and CHAVES, CRMM. Prevalência em crianças de fatores de risco para as doenças cardiovasculares. Cadernos de Saúde Pública, 2007, vol. 23, n. 9, p. 2239-2245. PMid:17700959. http://dx.doi.org/10.1590/ S0102-311X2007000900032

GIUGLIANO, R. and CARNEIRO EC. Fatores associados à obesidade em escolares. Jornal de Pediatria, 2004, vol. 80, n. 1, p. 17-22. http://dx.doi.org/10.2223/JPED.1128

GUEDES, DP., GUEDES, JERP., BARBOSA, DS., OLIVEIRA, JA. and STANGANELLI, LCR. Fatores de risco cardiovascular em adolescentes: indicadores biológicos e comportamentais. Arquivos Brasileiros de Cardiologia, 2006, vol. 86, n. 6, p. 439450. PMid:16810418. http://dx.doi.org/10.1590/S0066$782 \times 2006000600006$

GUERRA, AJM., TEIXEIRA, SN., SANTOS, LA., CARREIRO, E., MORAIS, MR. and PRATA, A. Avaliação nutricional infantil. Revisão Bibliográfica Metodologia: avaliação antropométrica, avaliação nutricional de comunidades infantis portuguesas. Revista Portuguesa de Pediatria, 1990, vol. 21, n. 5, p. 5-46.

GUERRA, AJM., TEIXEIRA, SN., GUERRA, FC., SANTOS, LA., CARREIRO, E. and JARDIN, H. Hábitos alimentares, estado de nutrição e lípidios séricos, numa população infantil dos 24 aos 59 meses: factores de risco de patologia cardiovascular. Revista Portuguesa de Pediatria, 1993, vol. 24, p. 3-44.

GUTIN, B., OWENS, S., SLAVENS, G., RIGGS, S. and TREIBER, F. Effect of physical training on heart-period variability in obese children. Journal of Pediatrics, 1997, vol. 130, n. 6, p. 938-943. http://dx.doi.org/10.1016/S0022-3476(97)70280-4

GRILLO, LP., CARVALHO, LR., SILVA, AC. and VERRESCHI, ITN. Influência das condições sócio-econômicas nas alterações nutricionais e na taxa de metabolismo de repouso em crianças escolares moradoras em favelas no município de São Paulo. Revista da Associação Médica Brasileira, 2000, vol. 46, n. l, p. 7-14. PMid:10770897. http://dx.doi.org/10.1590/S010442302000000100002

HALPERN, A., MANCINI, MC., CERCATO, C., VILLARES, SMF. and COSTA, APAC. Efeito do hormônio do crescimento sobre parâmetros antropométricos e metabólicos na obesidade andróide. Arquivos Brasileiros de Endocrinologia es Metabologia, 2006, vol. 50, n. 1, p. 68-73. PMid:16628277. http://dx.doi.org/10.1590/ S0004-27302006000100010

HERMSDORFF, HHM. and MONTEIRO, JBR. Gordura visceral, subcutânea ou intramuscular: onde está o problema? Arquivos Brasileiros de Endocrinologia es Metabologia, 2004, vol. 48, n. 6, p. 803-811. PMid:15761553. http://dx.doi.org/10.1590/ S0004-27302004000600005

HSUEH, WA. and LAW, R. The central role of fat and effect of peroxisome proliferator-activated receptor-g on progression of insulin resistance and cardiovascular disease. American Journal of Cardiology, 2003, vol. 92, n. 4A, p. 3j-9j. PMid:12957321.

INTERNATIONAL OBESITY TASK FORCE - IOTF. About obesity: incidence, prevalence \& comorbidity. 2002. Available from: <http://www.iotf.org>. Access in: 16/11/2007.

JIANG, X., SRINIVASAN, SR., URBINA, E. and BERENSON, GS. Hyperdynamic circulation and cardiovascular risk in children and adolescents: the Bogalusa heart study. Circulation, 1995, vol. 91, n. 4, p. 1101- 1106. PMid:7850947. http://dx.doi. org/10.1161/01.CIR.91.4.1101

LYON, CJ., LAW, RE. and HSUEH, W. Minireview: adiposity, inflammation, and atherogenesis. Endocrinology, 2003, vol. 144, n. 6, p. 2195-2200. PMid:12746274. http://dx.doi.org/10.1210/ en.2003-0285
MAFFEIS, C., TALAMINI, G. and TATÒ, L. Influence of diet, physical activity and parents' obesity on children' adiposity: a fouryear longitudinal study. International Journal of Obesity and Related Metabolic Disorders, 1998, vol. 22, n. 8, p. 758-764. PMid:9725635. http://dx.doi.org/10.1038/sj.ijo.0800655

MARQUES-LOPES, I., MARTI, A., MORENO-ALIAGA, MJ. and MARTINEZ, A. Aspectos genéticos da obesidade. Revista de Nutrição, 2004, vol. 17, n. 3, p. 327-338. http://dx.doi. org/10.1590/S1415-52732004000300006

McGILL JUNIOR, HC., GEER, JC. and STRONG, JP. Natural history of human atherosclerotic lesions. In SANDLER, M. and BOURNE, GH. (Eds.). Atherosclerosis and its origin. New York: Academic Press, 1963. p. 39-65.

MIRANDA, JMQM., SILVA, L., KOIKE, D., PALMEIRA, MV. and WICHI, RB. Prevalência de sobrepeso e obesidade em escolares do ensino público e privado na cidade São Paulo. Revista Brasileira de Atividade Física e Saúde, 2007, vol. 12, n. 2, p. 160.

MOURA, EC., CASTRO, CM., MELLIN, AS. and FIGUEIREDO, DB. Perfil lipídico em escolares de Campinas. Revista de Saúde Pública, 2000, vol. 34, n. 5, p. 499-505. PMid:11105114. http:// dx.doi.org/10.1590/S0034-89102000000500010

NOBRE,MRC., DOMINGUES, RZL., SILVA,AR., COLUGNATI, FAB. and TADDEI, JAAC. Prevalências de sobrepeso, obesidade e hábitos de vida associados ao risco cardiovascular em alunos do ensino fundamental. Revista da Associação Médica Brasileira, 2006, vol. 52, n. 2, p. 118-124. PMid:16767338. http://dx.doi. org/10.1590/S0104-42302006000200023

OLIVEIRA, CL., MELlO, MT., CINTRA, IP. and FISBERG, M. Obesidade e síndrome metabólica na infância e adolescência. Revista de Nutrição, 2004, vol. 17, n. 2, p. 237-245. http://dx.doi. org/10.1590/S1415-52732004000200010

OLIVEIRA, CS. and VEIGA, GV. Estado nutricional e maturação sexual de adolescentes de uma escola pública e de uma escola privada do Rio de Janeiro. Revista de Nutrição, 2005, vol. 8, n. 2, p. 183191, 2005.

PITANGA, FJG. and LESSA, I. Indicadores antropométricos de obesidade como instrumento de triagem para risco coronariano elevado em adultos na cidade de Salvador - Bahia. Arquivos Brasileiros de Cardiologia, 2005, vol. 85, n. 1, p. 26-31. PMid:16041451.

RABELO, LM. Fatores de risco para doença aterosclerótica na adolescência. Journal of Pediatrics, 2001, vol. 2, p. 153-64.

RAHMOUNI, K., CORREIA, ML., HAYNES WG. and MARK, AL. Obesity-associated hypertension: new insights into mechanisms. Hypertension, 2005, vol. 45, p. 9-14. PMid:15583075. http:// dx.doi.org/10.1161/01.HYP.0000151325.83008.b4

RAJALA, MW. and SCHERER, PE. Minireview: the adipocyteat the crossroads of energy homeostasis, inflammation, and atherosclerosis. Endocrinology, 2003, vol. 144, n. 9, p. 3765-3773. PMid:12933646. http://dx.doi.org/10.1210/en.2003-0580

SABIA, RV., SANTOS, E. and RIBEIRO, RPP. Efeito da atividade física associada à orientação alimentar em adolescentes obesos: comparação entre o exercício aeróbio e anaeróbio. Revista Brasileira de Medicina do Esporte, 2004, vol. 10, n. 5, p. 349-355.

SIGULEM, DM., TADDEI, JAAC., ESCRIVÃO, MAMS. and DEVINCENZI, MU. Obesidade na infância e na adolescência. Compacta: Temas em Nutrição e Alimentação, 2001, vol. 2, n. 1, p. 5-18.

SILVA, GA., BALABAN, G. and MOTTA, MEFA. Prevalência de sobrepeso e obesidade em crianças e adolescentes de diferentes condições socioeconômicas. Revista Brasileira de Saúde Materno Infantil, 2005, vol. 5, n. 1, p. 53-59. 
SOROF, J. and DANIELS, S. Obesity hypertension in children: a problem of epidemic proportions. Hypertension, 2002, vol. 40, n. 4 , p. 441-447. PMid:12364344. http://dx.doi.org/10.1161/01. HYP.0000032940.33466.12

STYNE, DM. Childhood and adolescent obesity: prevalence and significance. Pediatric Clinics of North America, 2001, vol. 48, n. 4, p. 823-853. http://dx.doi.org/10.1016/S00313955(05)70344-8

TITO, EF. Prática de atividade física em crianças obesas em faixa etária entre 8 a 12 anos. São Paulo, 2000.

TONSTAD, S., JOAKINSEN, O., STENSLAND-BUGGE, E., LEREN, TP., OSE, L., RUSSEL, D. and BONAA, KH. Risk factors related to carotid intima-media thickness and plaque in children with familial hypercholesterolemia and control subjects. Arteriosclerosis, Thrombosis, and Vascular Biology, 1996, vol. 16, n. 8, p. 984-991. http://dx.doi.org/10.1161/01.ATV.16.8.984
VALERA, FCP., DEMARCO, RC. and ANSELMO-LIMA, WT. Sindrome da apnéia e da hipopnéia obstrutivas do sono (SAHOS) em crianças. Revista Brasileira de Otorrinolaringologia, vol. 70, n. 2, p. 232-237, 2004. http://dx.doi.org/10.1590/S003472992004000200014

YOUNG-HYMAN, D., SCHLINDT, DG., HERMAN, L., DE LUCA, F. and COUNTS, D. Evaluation of the insulin resistance syndrome in 5- to 10 years-old over-weight/obese african-american children. Diabetes Care, 2001, vol. 24, n. 8, p. 1359-1364. PMid:11473070. http://dx.doi.org/10.2337/diacare.24.8.1359

Received December 12, 2013 Accepted April 11, 2014 